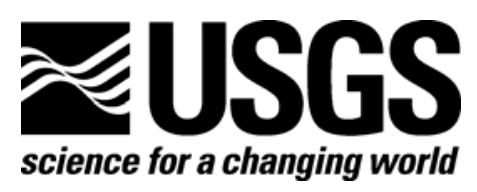

\title{
A Program for Partitioning Shifted Truncated Lognormal Distributions into Size-Class Bins
}

By Emil D. Attanasi and Ronald R. Charpentier

OFR -2007-1260 


\section{U.S. Department of the Interior DIRK KEMPTHORNE, Secretary}

\section{U.S. Geological Survey \\ Mark D. Myers, Director}

U.S. Geological Survey, Reston, Virginia 2007

For product and ordering information:

World Wide Web: http://www.usgs.gov/pubprod

Telephone: 1-888-ASK-USGS

For more information on the USGS - the Federal source for science about the Earth,

its natural and living resources, natural hazards, and the environment:

World Wide Web: http://www.usgs.gov

Telephone: 1-888-ASK-USGS

Suggested citation:

Attanasi, E.D. and Charpentier, R.R.., 2007, A program for partitioning shifted truncated lognormal distributions into size-class bins: U. S. Geological Survey Open-File Report OFR2007-1260, available online at http://pubs.usgs.gov/of/2007/1260/.

Any use of trade, product, or firm names is for descriptive purposes only and does not imply endorsement by the U.S. Government.

Although this report is in the public domain, permission must be secured from the individual copyright owners to reproduce any copyrighted material contained within this report. 


\section{Contents}

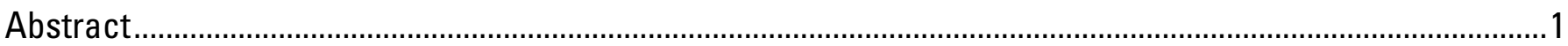

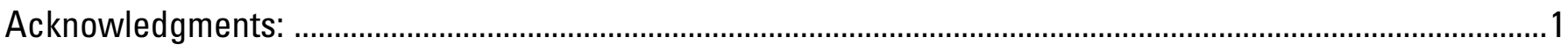

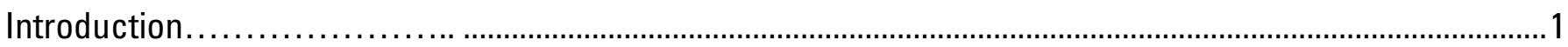

Shifted Trundated Lognormal Accumulation-Size Distribution ........................................................................

Size Frequency Distribution and Expected Volume of Resources in Undisovered Accumulations................3

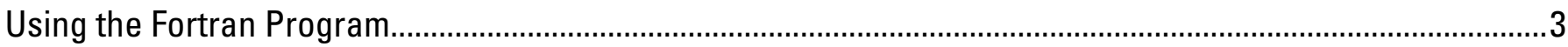

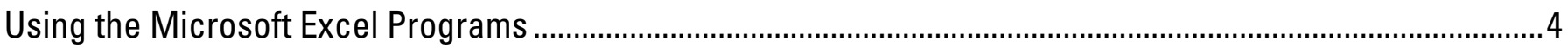

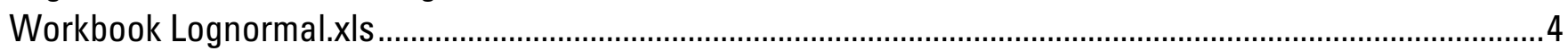

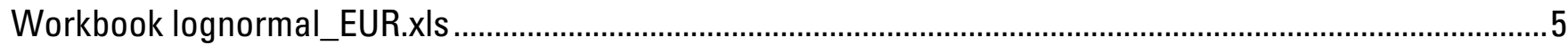

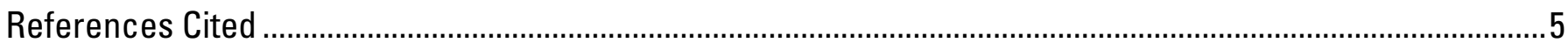

Appendix 1. Conventional Accumulation-Size Class Definitions ...................................................................

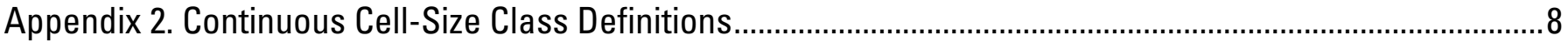

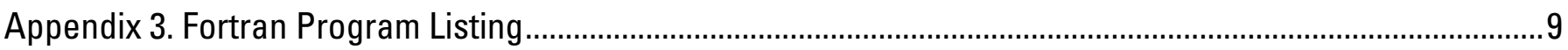

\section{Figures}

1. Shifted truncated lognormal distribution showing truncation at $f 001$ as well

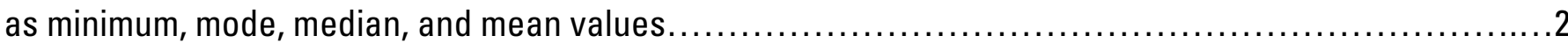

\section{Conversion Factors}

\begin{tabular}{lcc}
\hline \multicolumn{1}{c}{ Multiply } & By & To obtain \\
\hline Volume & & \\
\hline $\begin{array}{l}\text { barrel }(\mathrm{bbl}),(\text { petroleum, } \\
1 \text { barrel=42 gal) } \\
\text { cubic foot }\left(\mathrm{ft}^{3}\right)\end{array}$ & 0.1590 & cubic meter $\left(\mathrm{m}^{3}\right)$ \\
\hline
\end{tabular}




\title{
A Program for Partitioning Shifted Truncated Lognormal Distributions into Size-Class Bins
}

\author{
By Emil D. Attanasi and Ronald R. Charpentier
}

\begin{abstract}
In recent years, oil and gas accumulation-size frequency distributions have become a standard way to characterize undiscovered conventional oil and gas resources that have been postulated by geologic assessments. The preparation of such distributions requires the assessment geologists to explicitly choose parameters for the probability distribution for the sizes of undiscovered accumulations. The purpose of this report is to present a computational scheme for obtaining a binned size frequency distribution of undiscovered accumulations when the undiscovered accumulation size distribution is shifted truncated lognormal.
\end{abstract}

\section{Acknowledgements}

The authors are grateful to Dr. John Schuenemeyer, Southwest Statistical Consulting, LLC for reviewing the original Fortran code and suggesting the use of the normal distribution routines by Rolf E. Bargmann of the University of Georgia. The authors are also grateful to Philip Freeman and Troy Cook for suggestions.

\section{Introduction}

Many national, international, and regional assessments of undiscovered oil and natural gas have often presented their primary results as aggregate estimates of volumes of resources that are recoverable using current technology but without reference to specific economic costs. The determination of economic cost is, however, very much dependent on the size distribution of the "packages" in which the producible resource occurs.

To the economist or policy analyst the most useful way to convey the potential commercial value of the undiscovered resource volume is to characterize the undiscovered accumulations by the size frequency distribution. Not only is commercial value commonly determined by size, that is, the volume of recoverable resources in a postulated accumulation, but the size also affects how quickly and economically oil and gas accumulations are discovered. In recent years the size frequency distribution paradigm has become the standard way to characterize the undiscovered oil and gas resources, so that the assessment requires the geologist to explicitly choose parameters for the probability distribution for the sizes of undiscovered accumulations.

The purpose of this report is to present a computational scheme for obtaining a binned size frequency distribution of undiscovered accumulations when the undiscovered accumulation size distribution is a shifted truncated lognormal distribution. First, the analytical form of the shifted truncated lognormal distribution is presented. Then the computational scheme to calculate the binned undiscovered accumulation-size frequency distribution and the associated volume of contained resources is described. Programs to calculate this binned distribution are presented in 
two forms, a Fortran ${ }^{1}$ program and a Microsoft Excel® workbook. An additional Microsoft Excel ${ }^{\circledR}$ Workbook is included to calculate the similar cell-size distribution for assessments of continuous resources.

\section{Shifted Truncated Lognormal Accumulation-Size Distribution}

The shifted, right-truncated lognormal distribution used to model undiscovered accumulation sizes (figure 1) has a probability density function given by:

$$
f\left(y ; \mu_{Y}, \sigma_{Y}\right)=\frac{1}{F(T) \sigma_{Y} \sqrt{2 \pi}(y-\gamma)} \exp \left[-\frac{1}{2}\left(\frac{\ln (y-\gamma)-\mu_{Y}}{\sigma_{Y}}\right)^{2}\right], \gamma \leq y \leq T
$$

where $F(T)$ is the cumulative probability evaluated at the truncation point. The random variable $\mathrm{X}$ $=\ln (Y-\gamma)$ is normally distributed with mean $\mu_{X}$ and standard deviation $\sigma_{X}$. In figure 1 , the shift parameter, $\gamma$, is the distance that the generic lognormal distribution which starts at zero is shifted right. To take advantage of the normal distribution for computations $\mu_{X}$ and $\sigma_{X}$ must be calculated from parameters of the shifted truncated lognormal distribution. Following Aitchison and Brown (1957), then $\mu_{X}=\ln (f 50-\gamma)$, where $f 50$ is the median of the accumulation size distribution and $\sigma_{X}=\left(\ln (f 001-\gamma)-\mu_{X}\right) / \Phi^{-1}(0.999)$, where $f 001$ is the maximum accumulation size specified by the assessment geologist and the shift parameter, $\gamma$, is the minimum accumulation size specified by the geologist and the denominator of the expression for $\sigma_{X}$ is the inverse normal probability function. It is assumed that $1-F^{-1}(f 001)=0.001$, where $F^{-1}($.) is the inverse of the cumulative probability. The mean and variance of the truncated distribution can be obtained by numerical integration. Three sizes, namely $f 100$ (minimum), $f 50$ (median), and $f 001$ (maximum) are used to obtain the normal distribution that correspond to the un-truncated lognormal distribution.

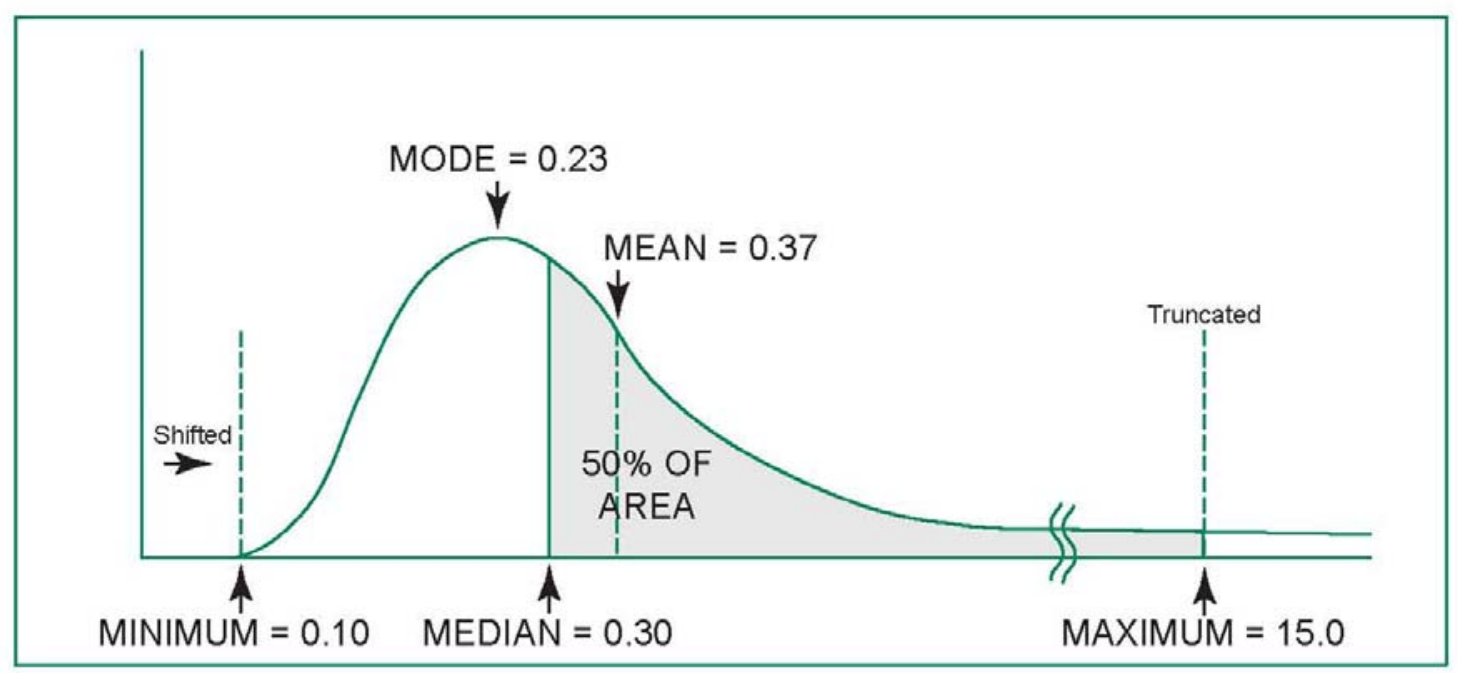

Figure 1 -Shifted truncated lognormal distribution showing truncation at the 001 (maximum size) as well as minimum, mode, median, and mean values (from Klett and Charpentier, 2003).

\footnotetext{
${ }^{1}$ Fortran is a general purpose, procedural programming language that is especially suited to numeric scientific computation.
} 
In recent oil and gas assessments prepared by the U. S. Geological Survey (USGS), the assessment geologists have been required to pick the minimum, median, and maximum sizes thought to describe the distribution of undiscovered accumulations. The right tail of the lognormal distribution is asymptotic to the horizontal axis, representing accumulation size. The finite maximum accumulation size specified by the geologist, or truncation point, was associated with the value at the 99.9 percentile of the parent lognormal distribution.

\section{Size Frequency Distribution and Expected Volume of Resources in Undiscovered Accumulations}

Size class probabilities were calculated using the estimated parameters $\left(\mu_{\mathrm{x}}\right.$ and $\sigma_{\mathrm{x}}$ ) in the cumulative normal distribution (in log space) that corresponded to the lognormal distribution for sizes in real space. The shifted truncated lognormal is transformed into a two parameter truncated lognormal by subtracting the minimum size value from the median and maximum accumulation values. In particular the value of the mean of the corresponding normal distribution in log space is the (natural) log of the median of this two-parameter lognormal distribution. The standard deviation of the corresponding normal is computed using the natural log of the distribution value at the 99.9 percentile and the natural $\log$ of the value at the median of the two parameter distribution as shown above.

The assessment geologists estimate a distribution for the number of undiscovered accumulations, conditional on the occurrence of at least one undiscovered accumulation of a defined minimum size. The mean of the conditional distribution for the number of undiscovered accumulations is risked by multiplying it by the play probability, defined as the occurrence probability of at least one undiscovered accumulation of the minimum size. The accumulation-size frequencies are computed as the product of the class probabilities and the risked expected number of undiscovered accumulations.

The expected volume of oil or gas in undiscovered accumulations can be computed as the product of the (risked) expected number of undiscovered accumulations and the expected value of the size distribution of undiscovered accumulations. Although the expected value of the untruncated distribution can be calculated analytically, the expected value of the shifted truncated lognormal distribution had to be done by numerical integration. The numerical integration algorithm was checked for accuracy by comparing results of selected cases with results obtained using the Maple V® (Waterloo Maple, 1998) mathematical analysis software package. Computations in Maple $\mathrm{V} ®$ are carried out in integer arithmetic and thus minimize round-off and truncation error.

The standard size-bin classifications are given in Appendices 1 and 2. The accumulationsize classification in Appendix 1 is for conventional accumulations. The cell-size classification in Appendix 2 is for assessment of continuous (unconventional) resources using the cell-based method. The Fortran version of the algorithm was originally summarized in Attanasi, Schuenemeyer, and Charpentier (2000).

\section{Using the Fortran Program}

Compile the Fortran program. Call the program with the compiled program name. The program default setting is the USGS accumulation size categories. The program will ask the user whether the distribution is of oil or gas accumulations. Then the program will require the user to enter the mean number of accumulations and the play probability. Computational results are 
provided as a size frequency distribution and the expected total volume of the primary product contained in the accumulation-size frequency distribution.

\section{Example of input query, with program queries in bold letters:}

Enter play id; up to 8 letters \& numbers

Campos

Are the accumulations gas accumulations? Y OR N

$\mathrm{N}$

Check accumulation type $=$ oil

Enter minimum accumulation size in millions of barrels or billions of cubic feet

6.

Enter median accumulation size in millions of barrels of billions of cubic feet

60.

Enter maximum accumulation size in millions of barrels or billions of cubic feet 4200.

Enter expected number of accumulations

75.

Enter play probability

1.

Example of output

Output file is dfq.prn

\begin{tabular}{|c|c|c|c|c|c|}
\hline Play/Area & type & class low & er \&upper & \multicolumn{2}{|c|}{ \# accumulations total oil or gas } \\
\hline Campos & oil & $0.5-$ & 1.0 & $\odot . \odot \odot \odot \odot$ & 10875 \\
\hline Campos & oil & $1.0-$ & 2.0 & $\odot .0 \odot \odot \odot$ & 10875 \\
\hline Campos & oil & $2.0-$ & 4.0 & $\odot .0 \odot \odot \odot$ & 10875 \\
\hline Campos & oil & $4.0-$ & 8.0 & 0.7238 & 10875 \\
\hline Campos & oil & $8.0-$ & 16.0 & 7.9538 & 10875 \\
\hline Campos & oil & $16.0-$ & 32.0 & 13.9879 & 10875 \\
\hline Campos & oil & $32.0-$ & 64.0 & 16.3910 & 10875 . \\
\hline Campos & oil & $64.0-$ & 128.0 & 14.8922 & 10875 \\
\hline Campos & oil & $128.0-$ & $256 . \odot$ & 10.7447 & 10875 \\
\hline Campos & oil & $256.0-$ & 512.0 & 6.1724 & 10875 \\
\hline Campos & oil & $512.0-$ & 1024.0 & 2.8178 & 10875 \\
\hline Campos & oil & $1024.0-$ & 2048.0 & 1.0198 & 10875 \\
\hline Campos & oil & $2048.0-$ & 4096.0 & 0.2920 & 10875 \\
\hline Campos & oil & $4096.0-$ & 8192.0 & $\odot .0046$ & 10875 . \\
\hline Campos & oil & $8192.0-$ & 16384.0 & $\odot .0 \odot \odot \odot$ & 10875 \\
\hline Campos & oil & $16384.0-$ & 32768.0 & $\odot .0 \odot \odot \odot$ & 10875 \\
\hline Campos & oil & $32768.0-$ & 65536.0 & $\odot .0 \odot \odot \odot$ & 10875 \\
\hline Campos & oil & $65536 . \odot-$ & 131072.0 & $\odot . \odot \odot \odot \odot$ & 10875 \\
\hline Campos & oil & expected & \# accumula & 75.0 & cumulation size \\
\hline
\end{tabular}

\section{Using the Microsoft Excel Programs}

\section{Workbook lognormal.xls}

This workbook is appropriate for use with conventional accumulations. The USGS methodology using these distributions for assessing conventional accumulations can be found in Schmoker and Klett (2000a, 2000b) and Klett, Schmoker, and Charpentier (2003).

All cells colored yellow are user-input cells. Units are in millions of barrels for liquids and billions of cubic feet for gas. On the Input worksheet, these specify whether the accumulations are 
oil or gas, the size distribution of undiscovered accumulations (minimum, median, and maximum), and the number of undiscovered accumulations. This number can be the mean number of undiscovered accumulations or any fractile of the distribution for number of accumulations. Also on the Input worksheet is an input cell (K14) specifying a cutoff value for a separate calculation of number of accumulations larger than that size. After entering the input, the user should click the Fit Distribution button to perform the calculations.

The number of accumulations larger than the cutoff size is given on the Input worksheet in cell K16. The rest of the output is given on worksheet Size Classes. The bins are specified and the frequencies of undiscovered accumulations are given in column G. The mean size of undiscovered accumulations is given in cell D25. Column F allows the user to specify the number of discovered accumulations in each bin. Discovered and undiscovered accumulations are plotted as a stacked bar chart.

\section{Workbook lognormal_EUR.xls}

This workbook is appropriate for use with continuous accumulations. The USGS methodology using these distributions for assessing continuous accumulations can be found in Klett and Charpentier (2003) and Klett and Schmoker (2003).

Again all cells colored yellow are user-input cells. Units are in millions of barrels for liquids and billions of cubic feet for gas. On the Input worksheet, these specify whether the cells are oil or gas and the size distribution of cells (minimum, median, and maximum) based on estimated ultimate recovery (EUR). No numbers of cells are input and the calculations on worksheet Size Classes are relative frequencies only. Also on the Input worksheet is an input cell (K14) specifying a cutoff value for a separate calculation of percent of cells larger than that size. After entering the input, the user should click the Fit Distribution button to perform the calculations.

The number of cells larger than the cutoff size is given on the Input worksheet in cell K16. The rest of the output is given on worksheet Size Classes. The bins are specified and the relative frequencies of cells are given in column F. The mean size of the cells is given in cell D25. Cellsize frequencies are plotted as a bar chart.

\section{References Cited}

Aitchison, J. and Brown, J.A.C., 1957, The lognormal distribution: Cambridge, Cambridge University Press, 176p.

Attanasi, E. D., Schuenemeyer, J. H. and Charpentier, R.R., 2000, Computation of the field-size frequency distributions, Appendix 1 of Klett, T.R., Charpentier, R.R., and Schmoker, J.W., 2000, Assessment operational procedures, chapter OP of U.S. Geological Survey World Energy Assessment Team, ed., U.S. Geological Survey World Petroleum Assessment 2000--Description and results: U.S. Geological Survey Digital Data Series DDS-60, p. 1-3.

Klett, T.R., and Charpentier, R.R., 2003, FORSPAN model users guide: U.S. Geological Survey Open-File Report 03-354, 37 p. http://pubs.usgs.gov/of/2003/ofr-03-354

Klett, T.R., and Schmoker, J.W., 2003, U.S. Geological Survey input-data form and operational procedure for the assessment of continuous petroleum accumulations, in USGS Uinta-Piceance Assessment Team, ed., Petroleum systems and geologic assessment of oil and gas in the Uinta- 
Piceance Province, Utah and Colorado: U.S. Geological Survey Digital Data Series DDS-69-B, p. 1-8. <http://pubs.usgs.gov/dds/dds-069/dds-069-b>

Klett, T.R., Schmoker, J.W., and Charpentier, R.R., 2003, U.S. Geological Survey input-data form and operational procedure for the assessment of conventional accumulations, in USGS UintaPiceance Assessment Team, ed., Petroleum systems and geologic assessment of oil and gas in the Uinta-Piceance Province, Utah and Colorado: U.S. Geological Survey Digital Data Series DDS69-B, p. 1-7. http://pubs.usgs.gov/dds/dds-069/dds-069-b

Schmoker, J.W., and Klett, T.R., 2000a, U.S. Geological Survey assessment model for undiscovered conventional oil, gas, and NGL resources-The seventh approximation, in U.S. Geological Survey World Petroleum Assessment 2000-Description and results: U.S. Geological Survey Digital Data Series DDS-60, p. 1-18. http://pubs.usgs.gov/dds/dds-060/

Schmoker, J.W., and Klett, T.R., 2000a, U.S. Geological Survey assessment model for undiscovered conventional oil, gas, and NGL resources-The seventh approximation: U.S. Geological Survey Bulletin 2165, p. 1-18. http://pubs.usgs.gov/bul/b2165/

Waterloo Maple, 1998, Maple V (release 5): Waterloo, Ontario, Maple Inc. 


\section{Appendix 1. Conventional Accumulation-Size Class Definitions}

\begin{tabular}{|c|c|c|}
\hline Class & $\begin{array}{c}\text { Oil accumulation size } \\
\text { (millions of barrels) }\end{array}$ & $\begin{array}{l}\text { Gas accumulation size } \\
\text { (billions of cubic feet) }\end{array}$ \\
\hline 1 & $0.03125-0.0625$ & $0.1875-0.375$ \\
\hline 2 & $0.0625-0.125$ & $0.375-0.75$ \\
\hline 3 & $0.125-0.25$ & $0.75-1.5$ \\
\hline 4 & $0.25-0.5$ & $1.5-3$ \\
\hline 5 & $0.5-1$ & $3-6$ \\
\hline 6 & $1-2$ & $6-12$ \\
\hline 7 & $2-4$ & $12-24$ \\
\hline 8 & $4-8$ & $24-48$ \\
\hline 9 & $8-16$ & $48-96$ \\
\hline 10 & $16-32$ & $96-192$ \\
\hline 11 & $32-64$ & $192-384$ \\
\hline 12 & $64-128$ & $384-768$ \\
\hline 13 & $128-256$ & $768-1,536$ \\
\hline 14 & $256-512$ & $1,536-3,072$ \\
\hline 15 & $512-1,024$ & $3,072-6,144$ \\
\hline 16 & $1,024-2,048$ & $6,144-12,288$ \\
\hline 17 & $2,048-4,096$ & $12,288-24,576$ \\
\hline 18 & $4,096-8,192$ & $24,576-49,152$ \\
\hline 19 & $8,192-16,384$ & $49,152-98,304$ \\
\hline 20 & $16,384-32,768$ & $98,304-196,608$ \\
\hline 21 & $32,768-65,536$ & $196,608-393,216$ \\
\hline 22 & $65,536-131,072$ & $393,216-786,432$ \\
\hline 23 & $131,072-262,144$ & $786,432-1,572,864$ \\
\hline
\end{tabular}

Accumulations that are exactly one of the boundary sizes belong to the higher class. For example, an accumulation of exactly 1 million barrels is in class 6 . 


\section{Appendix 2. Continuous Cell-Size Class Definitions}

\begin{tabular}{lcc}
\hline Class & $\begin{array}{c}\text { Oil cell size } \\
\text { (millions of barrels) }\end{array}$ & $\begin{array}{c}\text { Gas cell size } \\
\text { (billions of cubic feet) }\end{array}$ \\
\hline-1 & $0.0009765125-0.001953125$ & $0.005859375-0.01171875$ \\
0 & $0.001953125-0.00390625$ & $0.01171875-0.0234375$ \\
1 & $0.00390625-0.0078125$ & $0.0234375-0.046875$ \\
2 & $0.0078125-0.015625$ & $0.046875-0.09375$ \\
3 & $0.015625-0.03125$ & $0.09375-0.1875$ \\
4 & $0.03125-0.0625$ & $0.1875-0.375$ \\
5 & $0.0625-0.125$ & $0.375-0.75$ \\
6 & $0.125-0.25$ & $0.75-1.5$ \\
7 & $0.25-0.5$ & $1.5-3$ \\
8 & $0.5-1$ & $3-6$ \\
9 & $1-2$ & $6-12$ \\
10 & $2-4$ & $12-24$ \\
11 & $4-8$ & $24-48$ \\
12 & $8-16$ & $48-96$ \\
13 & $16-32$ & $96-192$ \\
14 & $32-64$ & $192-384$ \\
15 & $64-128$ & $384-768$ \\
16 & $128-256$ & $768-1,536$ \\
\hline
\end{tabular}

Cells that are exactly one of the boundary sizes belong to the higher class. For example, a cell of exactly 1 million barrels is in class 9. In order to apply the class size scale index, which was originally developed for conventional oil and non-associated gas accumulations, to well EUR values, size classes smaller than class one were defined. The two successively smaller size classes are denoted with indices 0 and -1 . 


\section{Appendix 3. Fortran Program Listing}

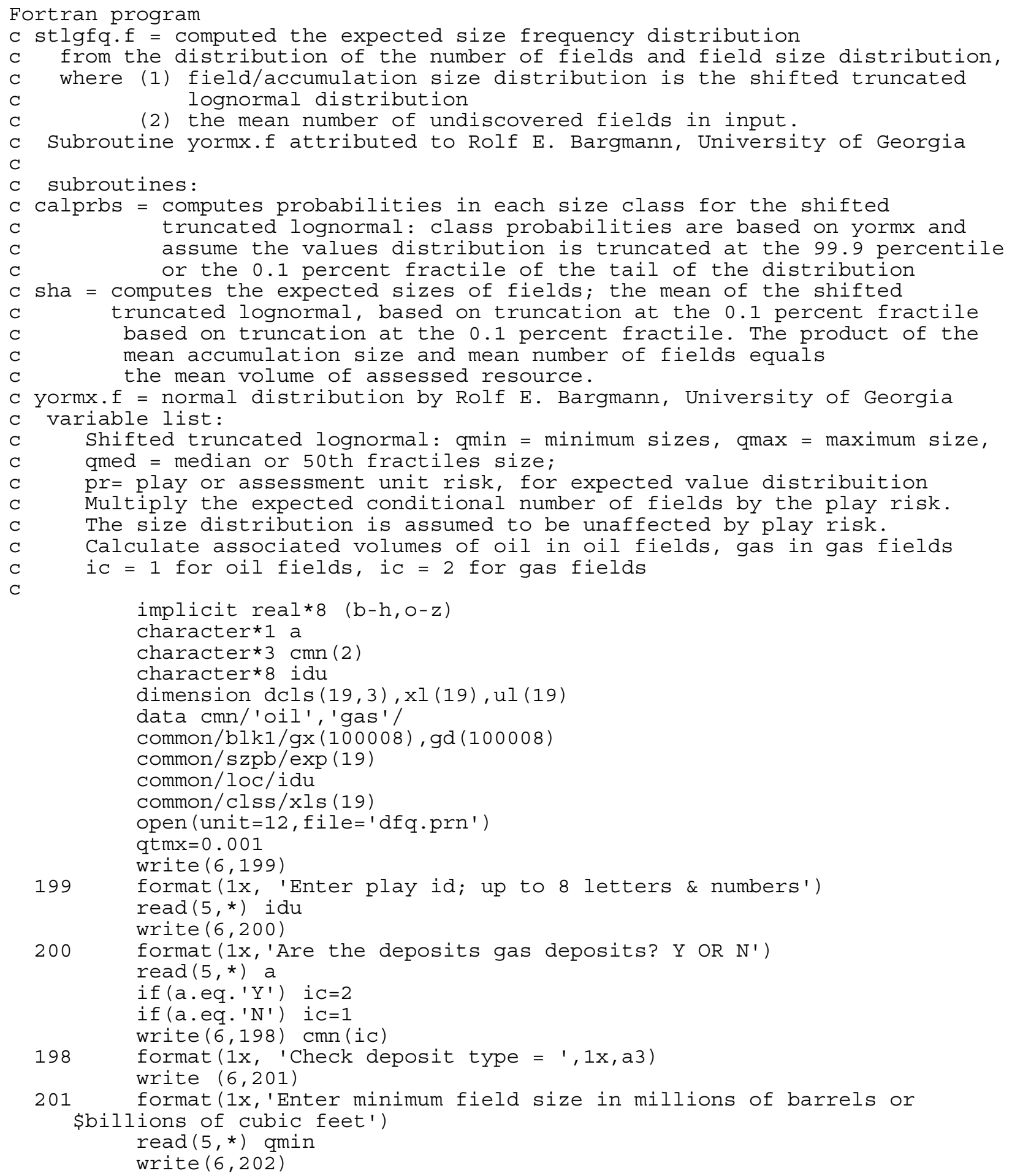




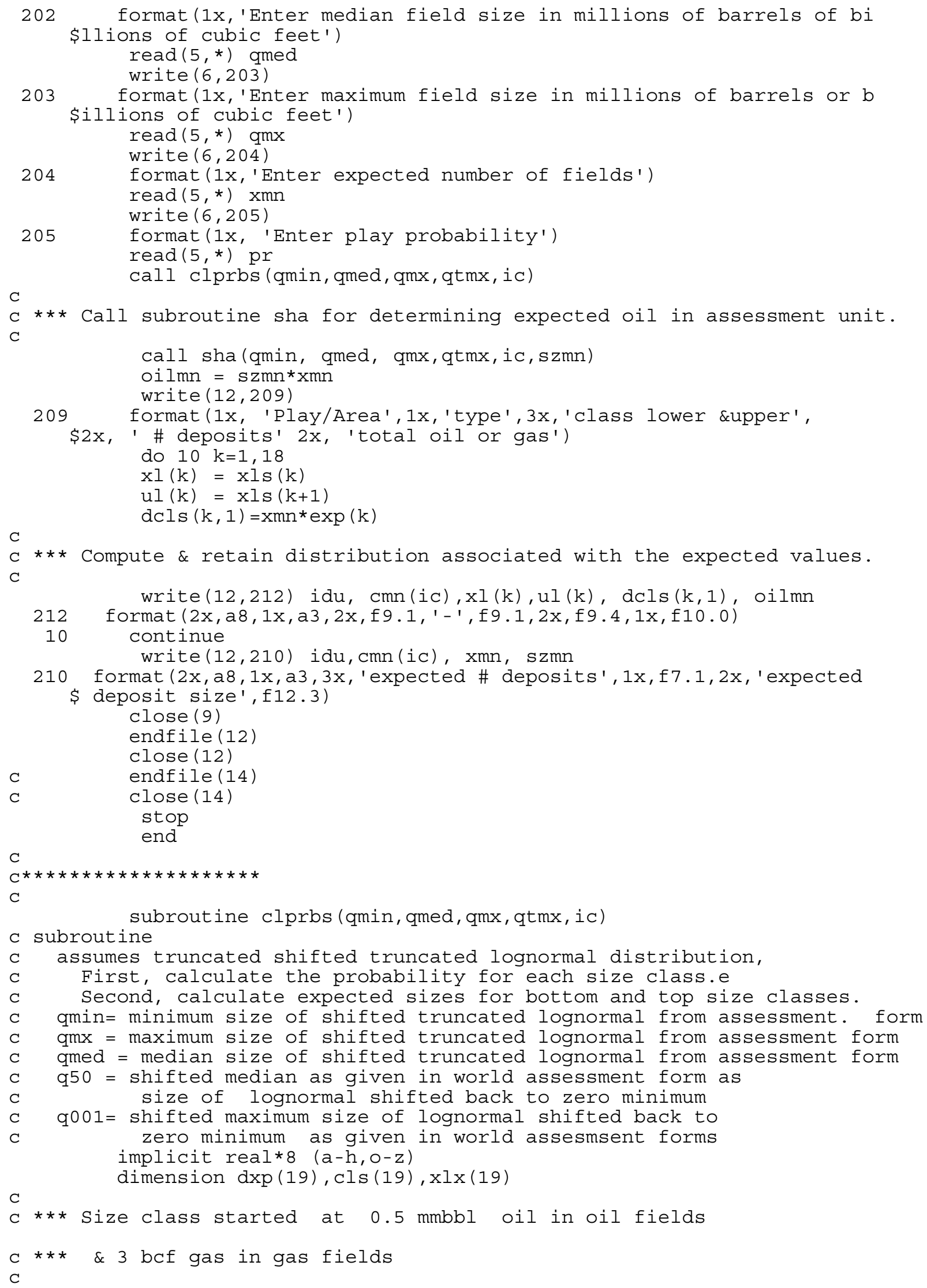




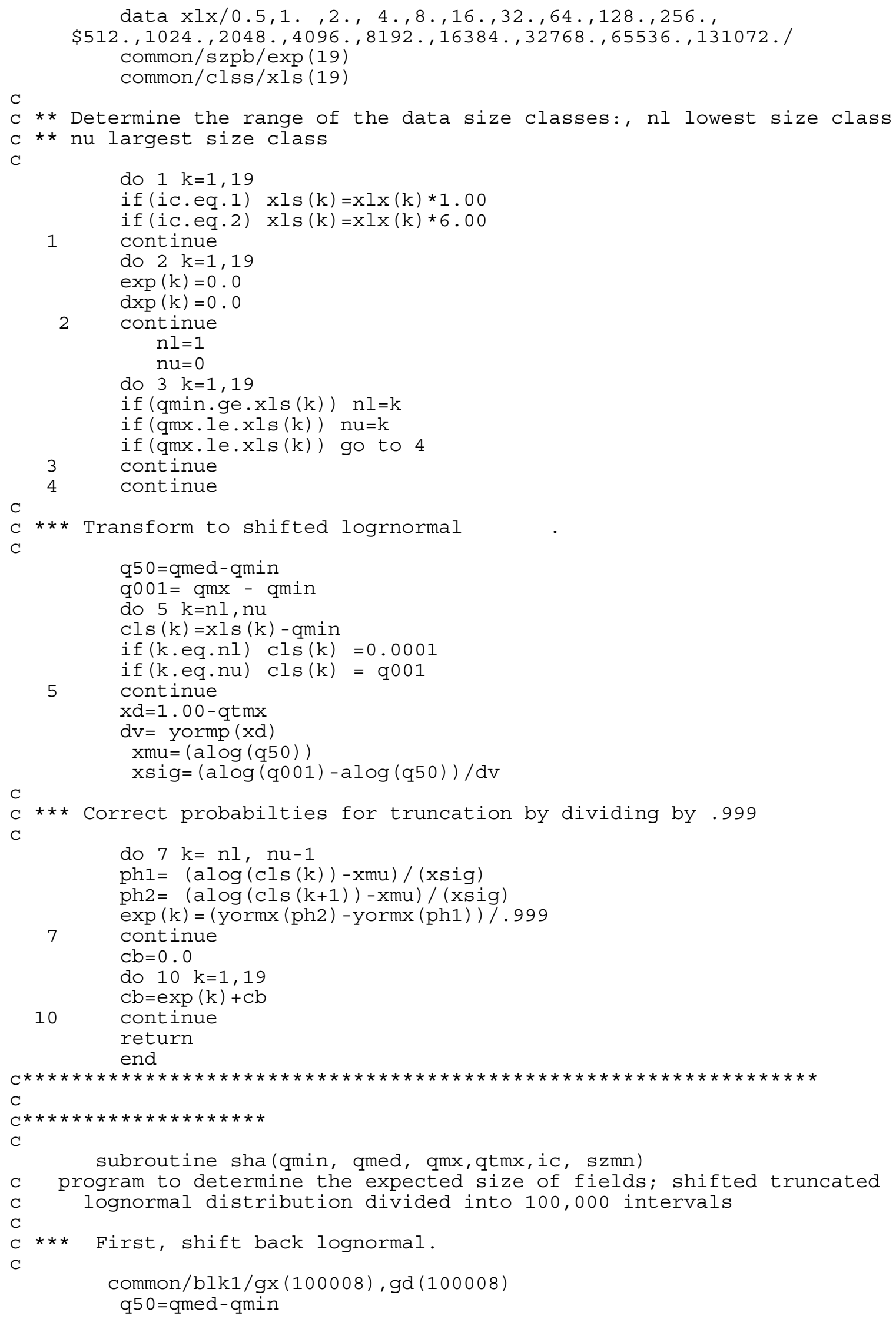




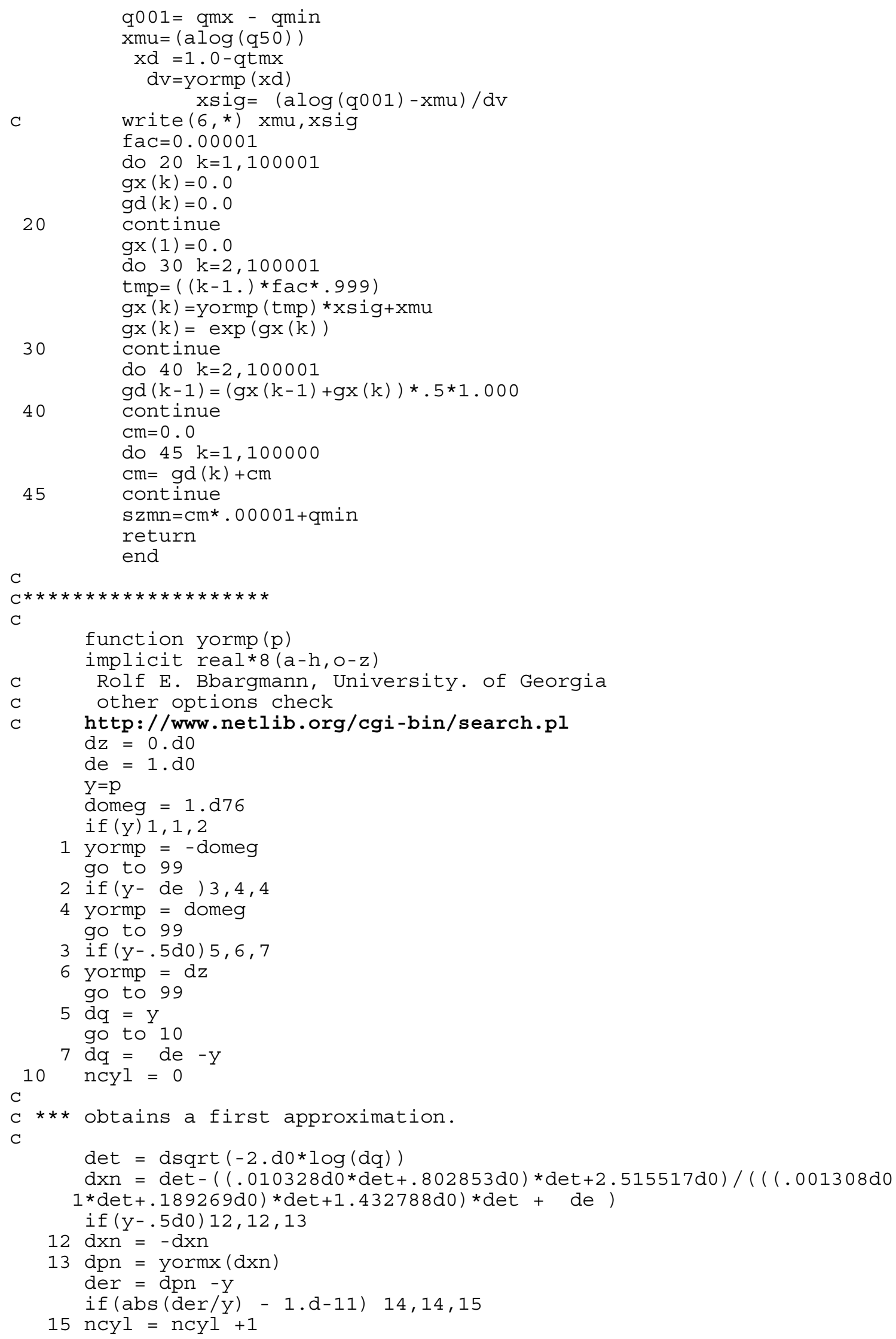




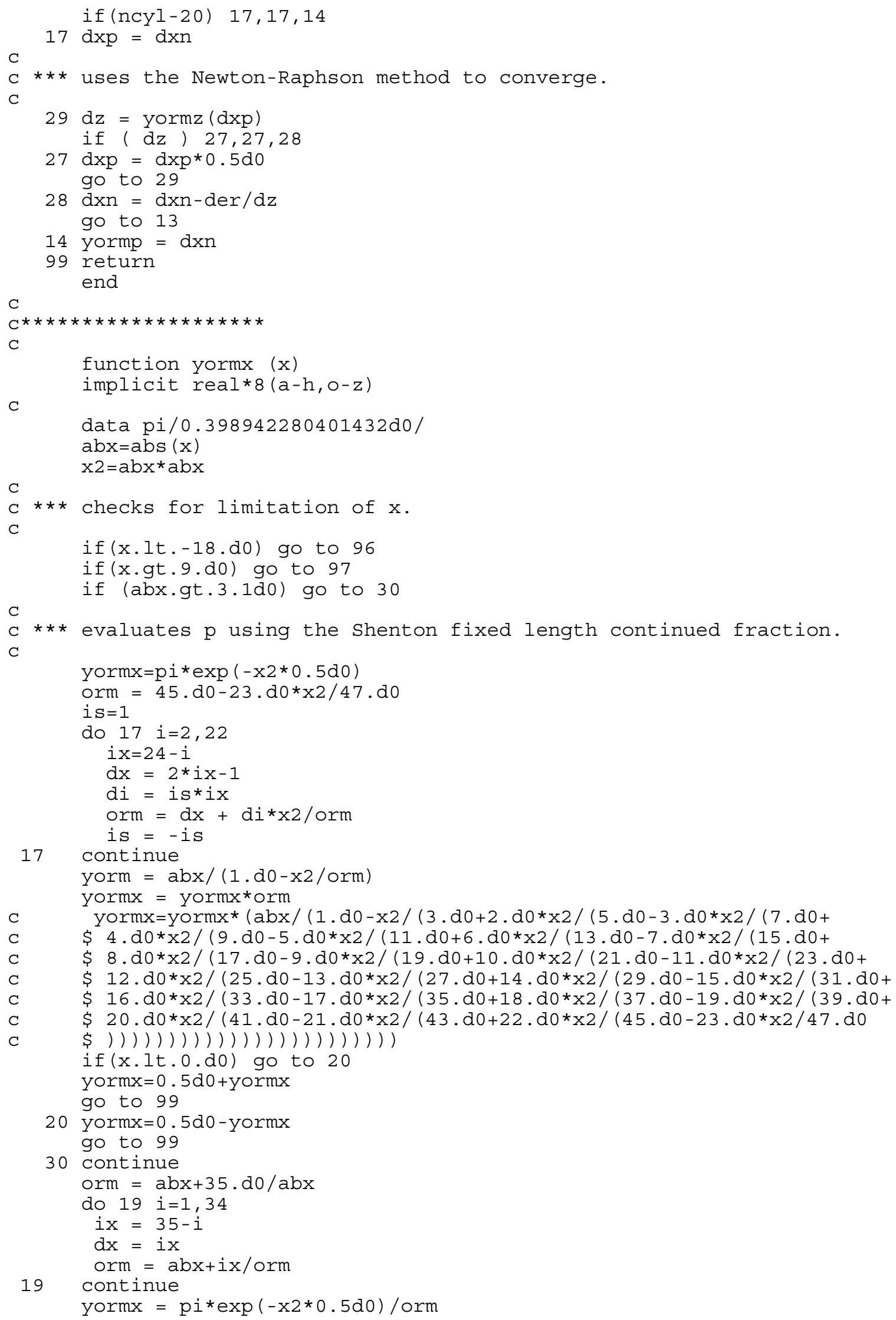




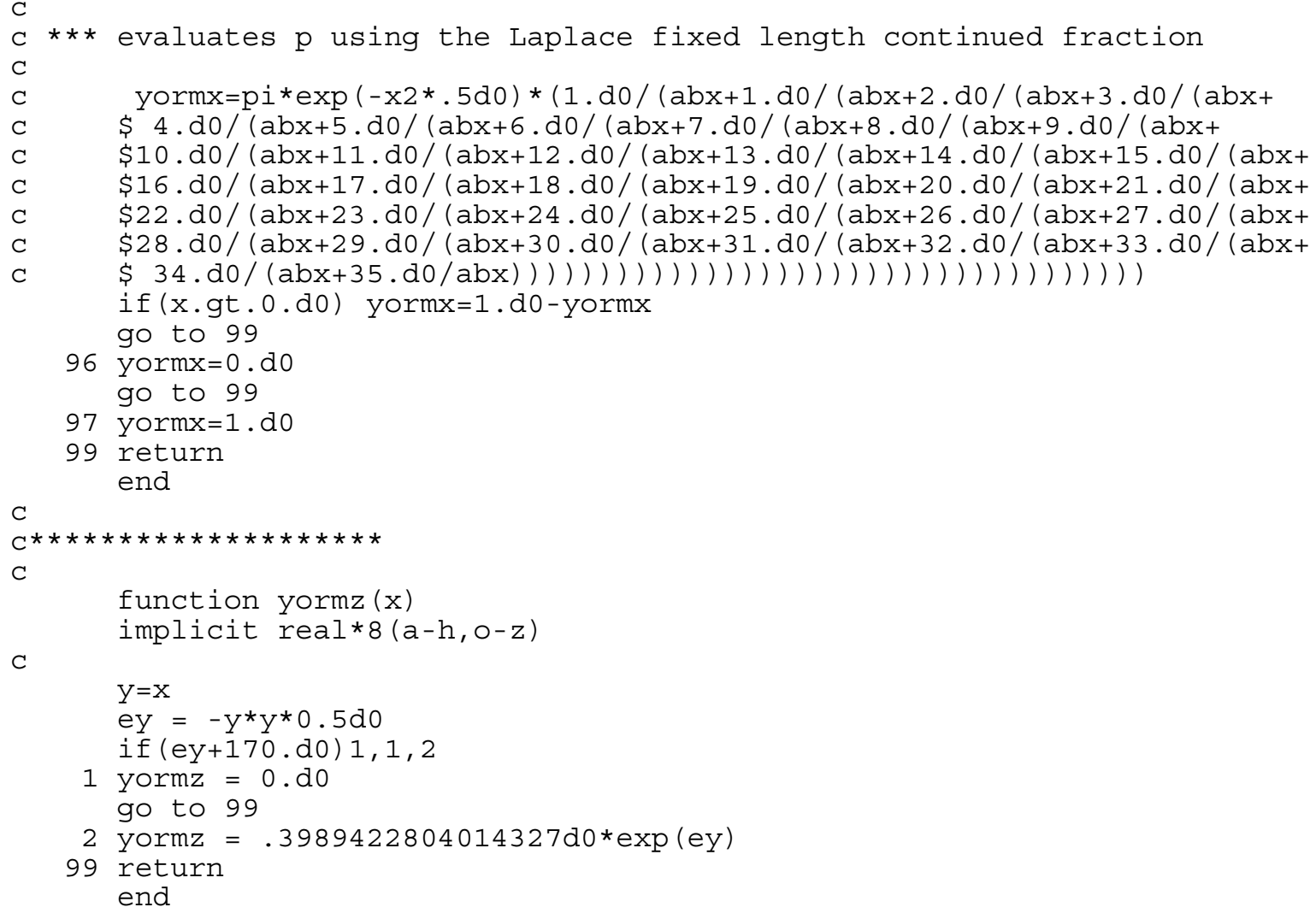

